doi: $10.2306 /$ scienceasia1513-1874.2014.40.278

\title{
Isolation and expression of FMOgs-ox1 from Korean radish
}

\author{
Yuyun Sugiharti, Mukhamad Su'udi, Sooyeon Lim, Jongkee Kim* \\ Department of Integrative Plant Science, Chung-Ang University, Anseong 456-756, Korea \\ *Corresponding author, e-mail: jkkim@cau.ac.kr
}

Received 24 Feb 2014

Accepted 25 Aug 2014

\begin{abstract}
Flavin monooxygenase (FMO) is one of the most important enzymes involved in glucosinolate biosynthesis. In this study, the full length of FMO gene (RsFMOgs-oxl) encoding a putative FMO protein composed of 450 amino acids was successfully cloned using the RACE-PCR method. The amino acid sequence of RsFMOgs-ox1 has high similarities of 92\% and 83\% with BrFMOgs-ox1 and AtFMOgs-ox1,2,3, respectively, and the gene structure of FMOgs-ox1 is similar to its plant homologues. Quantitative (qPCR) analysis revealed that RsFMOgs-oxl was highly expressed during early seedling development. In mature radish, the highest expression was observed in the leaves, while the lowest transcript was evident in the root. The expression of RsFMOgs-oxl was also regulated by wounding, notably 1 day after treatment. Subcellular localization in Arabidopsis showed that RsFMOgs-ox1 was localized in the cytoplasm and nuclei. This study allows us to understand something about RsFMOgs-oxl function in glucosinolate biosynthesis.
\end{abstract}

KEYWORDS: glucosinolate, RACE-PCR, real-time PCR, subcellular localization

\section{INTRODUCTION}

Radish (Raphanus sativus L.) is an edible root vegetable crop of the Brassicaceae family widely cultivated in the world, especially in Asia. This crop has been shown to have high glucosinolate content in comparison with other Brassicaceae members ${ }^{1}$. This vegetable has been considered as healthy food due to its valuable nutrient contents such as vitamin $\mathrm{C}$, potassium, magnesium, glucosinolate, and many other beneficial molecules (ndb.nal.usda.gov). Although more than 120 different kinds of glucosinolates have been reported in plants, the major glucosinolate in radish root is 4-methylthio-3-butenyl glucosinolate ${ }^{2}$ as the characteristic glucosinolate with the common name of glucoraphasatin ${ }^{3}$ (GRH).

Glucosinolate compounds have received much attention because their breakdown products display several potent bioactivities that serve as plant defence, as well as anticarcinogenesis compounds, especially in mammals. Flavin monooxygenase (FMO) is one of the important enzymes involved in glucosinolate biosynthesis. It catalyses the conversion of methylthioalkyl glucosinolate into methylsulphinyl glucosinolate through $S$-oxygenation. Isothiocyanate, a derived molecule from methylsulphinyl glucosinolate, has been proposed to be a key molecule conferring anticancer activity and plant defence ${ }^{4}$. In radish plant, 4-methylsulphonyl-3-butenyl isothiocyanate derived from glucoraphasatin has also been reported as a potent inducer of hepatic enzymes involved in the detoxification of chemical carcinogens ${ }^{5}$. Among several kinds of glucosinolates, GRH and glucoraphenin (GRE) have been shown to be able to induce phaseII xenobiotic metabolising enzymes with different induction profiles. Compare to GRH, low dosage of GRE is sufficient to trigger the cytochrome P-450 (CYP)-associated monooxygenases and the postoxidative metabolism ${ }^{6}$.

To date, most of the FMO genes responsible to convert methylthioalkyl glucosinolate into methylsulphinyl glucosinolate have been identified and characterized in Arabidopsis ${ }^{4,7}$. There are five FMO genes (FMOgs-ox1-5) which have been reported to be involved in glucosinolate biosynthesis in Arabidopsis. FMOgs-ox2, FMOgs-ox3 and FMOgs-ox4 show broad substrate specificity and catalyse the conversion of methylthioalkyl glucosinolate to methylsulphinylalkyl glucosinolate. In contrast, FMOgs-ox5 shows substrate specificity against the long-chain 8methylthiooctyl glucosinolate ${ }^{7}$.

At the cellular level, aliphatic glucosinolate biosynthesis occurs in the cytoplasm, chloroplast and endoplasmic reticulum (ER), in which the initial deamination process is catalysed by BCTA4 enzyme in the cytoplasm ${ }^{8}$. In the next step, the side chain elongation is mediated by MAM enzymes in the chloroplast ${ }^{9}$. Finally, the core structure formation is 
catalysed by enzymes localized in the ER-membrane such as CYPs ${ }^{10-12}$.

A recent report on subcellular localization of FMO in Arabidopsis revealed that FMOgs-ox1 basically located in vascular tissues, endodermis flower stalk and epidermal cells in the leaf ${ }^{13}$. Transient expression study using tobacco leaves also indicated that FMOgs-ox1 is a cytosolic protein. In the radish however the functional study of FMO, including gene expression, subcellular localization and other molecular characterization, has not been reported. In this study, the molecular properties of RsFMOgs-oxl were characterized, and its potential role in the glucosinolate biosynthesis is discussed. The result of this study would be valuable for future vegetable research related with anti-carcinogenic compound.

\section{MATERIALS AND METHODS}

\section{Plant materials and growth condition}

Radish ( $R$. sativus L.) inbred line Chungguk chongpi was used for all experiments. Seeds were sterilized with $70 \%$ ethanol and washed with distilled water to remove the seed coat, and then germinated in Murashige and Skoog medium ${ }^{14}$. For RNA extraction and other experiments, the radish seedling (sprouts) were harvested at indicated time, immediately frozen in liquid nitrogen, and stored at $-80{ }^{\circ} \mathrm{C}$ until use.

\section{RNA isolation and cloning}

Samples were collected from seed, sprout at 3, 5, 7, 9, and 11 days after germination, shoot, leaf, stem, inflorescence, flower, pod, and root. The total RNA from each sample was isolated using RNeasy Mini Kit (Qiagen, Valencia, CA, USA) according to manufacturer's instruction. For cDNA synthesis, $1 \mu \mathrm{g}$ of total RNA were mixed with oligo (dT) $)_{18}$ primer and incubated at $70^{\circ} \mathrm{C}$ for $5 \mathrm{~min}$. Subsequently, the samples were mixed with RT-premix consisting of buffer, dNTP and reverse transcriptase (Bioneer, Daejon, Korea) in a total volume of $20 \mu \mathrm{l}$ and incubated at $42{ }^{\circ} \mathrm{C}$ for $90 \mathrm{~min}$. The reverse transcriptase was inactivated by incubating the mixture at $95^{\circ} \mathrm{C}$ for 5 min.

For cloning RsFMOgs-oxl, the $P f u-x$ polymerase (Solgent, Daejeon, Korea) was used to amplify the target gene. For the first cloning of RsFMOgs-oxl (668 bp), $1.0 \mu \mathrm{l}$ of the cDNA sample was used as a template in a $50 \mu \mathrm{l}$ total reaction mix containing degenerate primers $R s F M O$-forward ( $5^{\prime}$-ATG GCA CCA GCT CAA AAC YCA ATC AGT TC- $3^{\prime}$ ) and $R s F M O$-reverse $\left(5^{\prime}\right.$-ACG TCT CTA CTA ATA TCA CTA CCG CTC GC-3'). The PCR mixture was initially denatured at $95^{\circ} \mathrm{C}$ for $5 \mathrm{~min}$ and then subjected to 40 cycles of the following conditions: $95^{\circ} \mathrm{C}$ for $15 \mathrm{~s}, 53{ }^{\circ} \mathrm{C}$ for $15 \mathrm{~s}$, and $72^{\circ} \mathrm{C}$ for $1 \mathrm{~min}$, with a final extension at $72{ }^{\circ} \mathrm{C}$ for $5 \mathrm{~min}$. The PCR products were analysed on a $1 \%(\mathrm{w} / \mathrm{v})$ agarose gel containing ethidium bromide. The fragment was purified using gel purification system (Qiagen, Valencia, CA, USA), A-tailed, and cloned into pGEM-T Easy vector (Promega, Madison, WI, USA) using standard cloning procedures ${ }^{15}$.

\section{RACE-PCR}

For cloning the full-length RsFMOgs-oxl, $3^{\prime}$ RACEPCR was performed using $3^{\prime}$ RACE System Kit according to the manufacturer's instructions (Invitrogen, USA). Briefly, the first strand cDNA was synthesized with SuperScript II reverse-transcriptase. A $2.0 \mu \mathrm{l}$ sample of the cDNA was used for subsequent PCR amplification in a total volume of $50 \mu \mathrm{l}$. The gene specific primer used for PCR amplification was 5'-CGA ATG GCA CCA GCT CAA AAC CCA AT- ${ }^{\prime}$ in combination with abridged universal amplification primer (Invitrogen, USA). The PCR mixture was initially denatured at $94^{\circ} \mathrm{C}$ for 3 min and then subjected to 35 cycles of the following conditions: $94^{\circ} \mathrm{C}$ for $15 \mathrm{~s}, 53^{\circ} \mathrm{C}$ for $15 \mathrm{~s}$, and $72^{\circ} \mathrm{C}$ for $2 \mathrm{~min}$, with a final extension at $72{ }^{\circ} \mathrm{C}$ for $5 \mathrm{~min}$. Gel purification and cloning procedures were carried out as described above.

\section{Sequence analysis and alignment}

The nucleotide sequence obtained from cloning work was used for the next sequence analysis. Amino acid sequence was obtained by translating the nucleotide sequence using the Translation program ${ }^{16}$ (www.bioinformatics.org/sms/index.html). To determine the identity between the RsFMOgs-ox 1 protein and similar proteins from other species, the amino acid sequences were analysed using the NCBI-BLAST program $^{17,18}$ (blast.ncbi.nlm.nih.gov/Blast.cgi). The conserved domain of RsFMOgs-ox1 was determined by BLASTP and prosite ${ }^{19}$ (www.expasy.ch/prosite).

\section{Quantitative real-time PCR}

For quantitative real time PCR (qPCR), $1 \mu \mathrm{l}$ cDNAs prepared from several organs were used as template in the SYBR Green PCR Master mix (Bioneer, Daejon, Korea) in a total volume of $25 \mu \mathrm{l}$. The primers used for qPCR were 5'-CAG GCA TGG GCA TAC AAT TC-3' and $5^{\prime}$-TCT TCT GCG ACC CAG TCA AG-3'. The PCR conditions were $95^{\circ} \mathrm{C}$ for $10 \mathrm{~min}, 40$ cycles of $10 \mathrm{~s}$ at $95^{\circ} \mathrm{C}, 10 \mathrm{~s}$ at $60^{\circ} \mathrm{C}$, and $10 \mathrm{~s}$ at $72^{\circ} \mathrm{C}$. Samples were prepared in triplicate. The amplification 
of target genes was analysed using the Optical System (7500 Real-time PCR software version 2.0) provided with the AB 7500 cycler (Applied Biosystems, Foster City, USA). The relative expression levels of each transcript were obtained by normalization to the radish RNA polymerase II (RPII) gene ${ }^{20}$. Calculation was based on the comparison of the distinct cycle determined by cycle threshold values $(\mathrm{Ct})$ at a constant level of fluorescence. The delta-delta $\mathrm{Ct}$ method $^{21}$ was employed for final data analysis.

\section{Subcellular localization}

The open reading frame (ORF) of RsFMOgs-oxl was PCR-amplified using $P f u$-x polymerase with primer set as follows: RsFMO-GFPF (5'-GAA TTC ATG GCA CCA GCT CAA AAC CCA ATC- $\left.3^{\prime}\right)$ and $R s F M O-G F P R \quad\left(5^{\prime}\right.$-GCGGATCCC TAG CTA ATC AAC TTC TTA CTA GCA-3'). The enzyme sites for $E c o$ RI and BamHI are underlined. PCR product were digested with EcoRI and BamHI, and ligated into pEGAD vector ${ }^{22}$ to create the construct of pEGADRsFMOgs-oxl. The pEGAD-RsFMOgs-oxl construct and pEGAD vector (control) was separately introduced into Agrobacterium tumefaciens strain GV3101 by the heat shock method. The Agrobacterium cell harbouring the construct was transformed into Arabidopsis Col-0 to generate a transgenic plants carrying stable GFP expression using the floral dipping $\operatorname{method}^{23}$. Selection for transgenic lines was conducted as described previously ${ }^{24} . \mathrm{T}_{2}$ seeds were grown on MS media for 1 week prior to microscopic analysis.

\section{RESULTS}

\section{Cloning of RsFMOgs-ox1 and its molecular characterization}

In the beginning, the sequence information derived from wild radish ( $R$. raphanistrum) end-sequence $\operatorname{tags}^{7}$ was utilized for primer design. By using cDNA template isolated from commercial radish (R. sativus L.), the expected 668-bp PCR product was obtained (Fig. 1a). This partial sequence covered the start codon (ATG) similar to previously reported RsFMOgs-oxl from other plants. However, conventional PCR approach for isolating the C-terminal region to clone the RsFMOgs-oxl gene was unsuccessful. To overcome this problem, the rapid amplification of cDNA ends (RACE)-PCR method was applied to obtain the remaining sequence in the $\mathrm{C}$-terminal part. After collecting the nucleotide sequence in the $\mathrm{C}$ terminal part, the primer set for amplification the open reading frame (ORF) of RsFMOgs-oxl was designed (a)

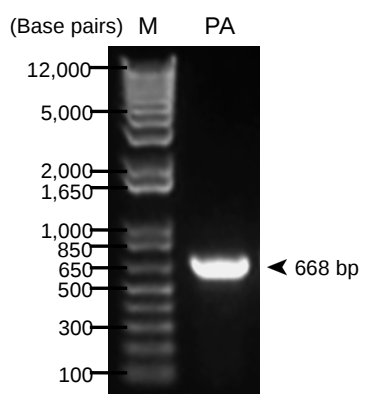

(b)

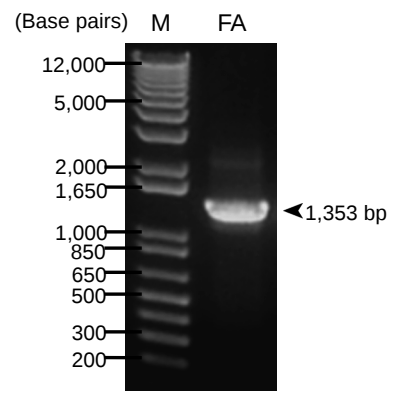

Fig. 1 Cloning of RsFMOgs-oxl. PCR amplification of partial RsFMOgs-oxl using (a) normal PCR and (b) fulllength RsFMOgs-oxl with $3^{\prime} \mathrm{RACE}-\mathrm{PCR}$; $M$, marker; $P A$, partial amplicon; $F A$, full amplicon.

(forward, 5'-ATG GCA CCA GCT CAA AAC CCA ATC-3'; reverse, CTA GCT AAT CAA CTT CTT ACT AGC A- $3^{\prime}$ ) and used for subsequent cloning PCR. As shown in Fig. 1b, the amplicon size resulted from this reaction is $1353 \mathrm{bp}$, relatively similar size with RsFMOgs-oxl from other plant species reported previously $^{4,7}$.

The PCR product was then cloned into the Tvector and confirmed by sequencing. The sequence were analysed and compared with RsFMOgs-ox homologues from other plant species. The RsFMOgsoxl composed of $1353 \mathrm{bp}$ encodes a polypeptide of 450 amino acid residues with a calculated molecular mass (Mw) of $50.7 \mathrm{kDa}$ and an isoelectric point (pI) of 5.79. FAD- and NADPH-binding motif (GxGxxG) is located in the N-terminal and central regions, respectively, (Fig. 2a). In addition, FMO identifying motif (FxGxxxHxxxY/F) is determined to be located at amino acid between 324 and 334 in the C-terminal region of RsFMOgs-ox1 protein.

Phylogenetic tree was generated by comparing RsFMOgs-ox 1 protein with its homologues from other plant species. The result showed that RsFMOgsox1 has high identity $(92 \%)$ and located in the same cluster with FMOgs-ox1 from Brassica rapa (BrFMOgs-ox1) (Fig. 2b). Hence our RsFMO clone is designed as RsFMOgs-ox1.

\section{Expression pattern of RsFMOgs-ox 1}

In previous reports, the FMOgs-ox member in Arabidopsis expressed in several organs such as leaves, flowers, and seeds ${ }^{4,25,26}$. In this study, the quantitative real-time PCR (qPCR) was performed to determine the expression pattern of RsFMOgs-oxl. Total RNA from seed, seedling (sprout) at several stages, and 
(a)

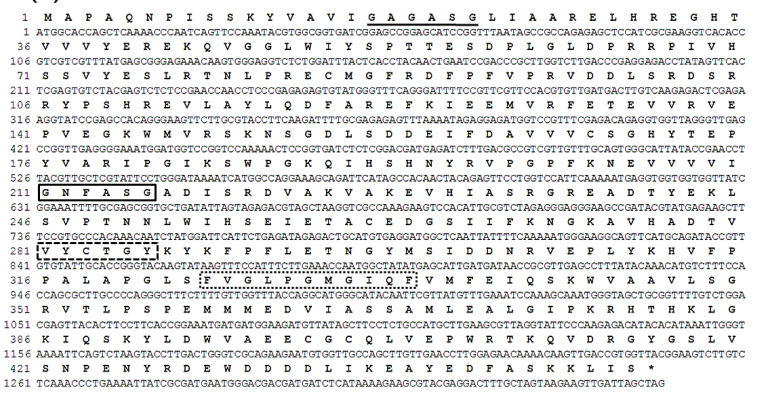

(b)

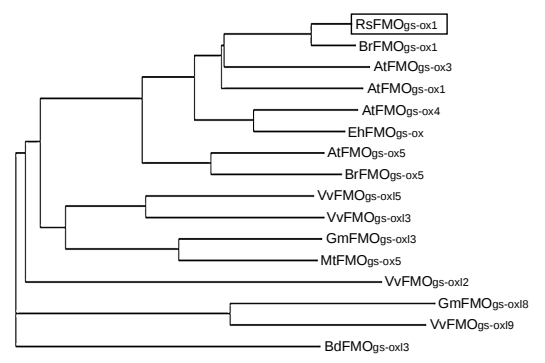

Fig. 2 Sequence of RsFMOgs-oxl and phylogenetic tree analysis. (a) Nucleotide and deduced amino acid sequences of RsFMOgs-oxl. The FAD binding site is underlined and the NADPH binding motif is boxed (bold line). The conserved motifs for FMO family are boxed with dashed- and dotted-lines, respectively. (b) Phylogenetic comparison of RsFMOgs-ox1 to other plant FMOgs-ox homologues. BrFMOgs-ox1 (accession no. ACR10274.1), AtFMOgs-ox3 (NP 176444.1), AtFMOgs-ox1 (NP 176761.1), AtFMOgs-ox4 (NP 564797.1), EhFMOgs (ABJ98059.1), AtFMOgs-ox5 (NP 172678.3), BrFMOgsox5 (ACR10275.1), VvFMOgs-ox15 (XP 003631450.1), VvFMOgs-oxl3 (XP 003631451.1), GmFMOgs-oxl3 (XP 003538706.1), MtFMOgs-ox5 (XP 003611271.1), VvFMOgs-ox12 (XP 002265001.1), GmFMOgs-ox18 (XP 003524682.1), VvFMOgs-ox19 (XP 002281491.2), BdFMOgs-oxl3 (XP 003562230). Phylogenetic tree shows a graphical representation of evolutionary relationships and were constructed using the EBI-CLUSTALW algorithm. Rs, Raphanus sativus; Br, Brassica rapa; At, Arabidopsis thaliana; Eh, Eutrema halophilum; Mt, Medicago truncatula; Vv, Vitis vinifera; Gm, Glycine max; Bd, Brachypodium distachyon.

other organs were prepared and used as templates in the qPCR reaction. Weak transcriptional level was observed in seeds. During seedling development, the highest expression of RsFMOgs-oxl was observed 5 days after germination (Fig. 3a). The expression of RsFMOgs-oxl was also examined in vegetative organs (stem, leaves, roots) and generative organs such as inflorescence, flower, and pod. Among them, leaves
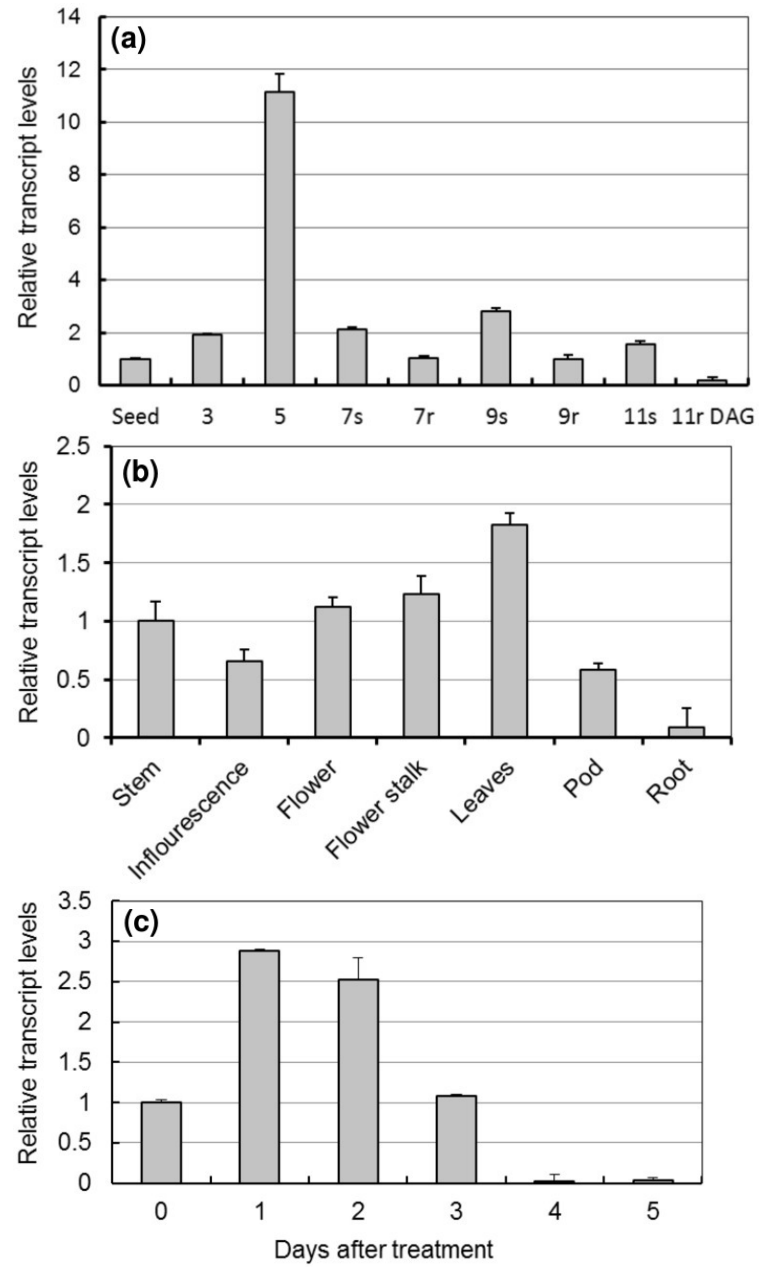

Fig. 3 Expression pattern of RsFMOgs-oxl. The expression of RsFMOgs-oxl gene in (a) seedling, (b) radish organs, and (c) in response to wounding treatment; $s$, shoot; $r$, root; $D A G$, days after germination.

and roots showed the highest and lowest expression of RsFMOgs-oxl, respectively, (Fig. 3b). In addition to organ specific expression, the transcriptional level of RsFMOgs-oxl was also explored under a wounding treatment. The leaves were wounded with scissors and harvested at indicated time (Fig. 3c). The results showed that RsFMOgs-oxl transcript was high at 1 and 2 days after treatment (Fig. 3c).

\section{Subcellular localization of RsFMOgs-ox1}

Localization within the cell can explain the protein's function. Arabidopsis FMOgs-ox1 has been reported to be localized in cytoplasm ${ }^{13}$. To investigate the subcellular localization of RsFMOgs-ox1, the ORF of RsFMOgs-oxl was fused to the C terminus of GFP and expressed under the control of the $35 \mathrm{~S}$ promoter. 
(a)

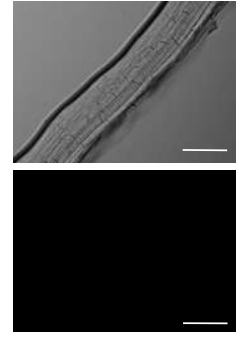

WT

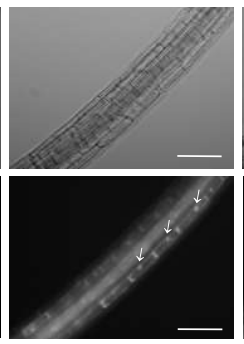

GFP vector WT (b)

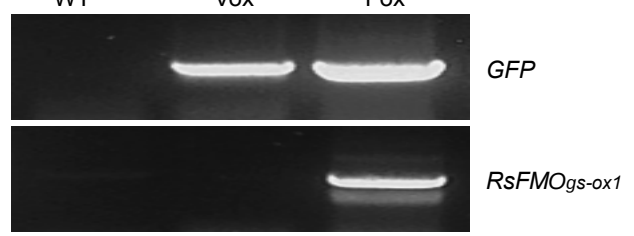

Fig. 4 Subcellular localization of RsFMOgs-ox1. (a) The vector constructs were stably expressed in Arabidopsis transgenic lines. One week Arabidopsis roots were observed under bright light (upper panel) and GFP channel (lower panel). The arrow indicates nuclei. (b) PCR result confirmed the successful transformation. WT, nontransformant; Vox, Arabidopsis transformed with vector control; Fox, Arabidopsis transformed with GFPRsFMOgs-oxl.

The resulting gene fusion (35S:GFP-RsFMOgs-oxl) and empty vector, $\mathrm{pEGAD}^{22}$, was separately transformed into Arabidopsis thaliana. As shown in Fig. 4a, RsFMOgs-ox1 appeared to be localized in the nucleus and cytoplasm. To confirm a successful transformation in Arabidopsis, the genomic DNA isolated from seedling was used as templates in the PCR mixture with specific primer set for GFP and RsFMOgs-oxl. The results showed that the constructs were successfully introduced in the system (Fig. 4b).

\section{DISCUSSION}

The availability of gene bank or whole genomic sequences in certain species is an essential factor for convenience and successful cloning work. Up to date, the complete genome sequence is available for the model plant Arabidopsis ${ }^{27}$. The gene bank for several crops and vegetables such as rice and tomato have also been released ${ }^{28,29}$. However, radish ( $R$. sativus L.) whole genomic sequence is still partially available although has been released to the public ${ }^{30}$. In this study, the cloning work for RsFMOgs-oxl using the RACE-PCR ${ }^{31}$ is reported. The RACE-PCR method was selected since gene screening using cDNA library in combination with DNA probe labelling is quite time consuming and laborious. Several genes from plants with limited genome sequence information, such as peach, seepweeds, and azuki bean, were isolated with above approach ${ }^{32-34}$. Using RACE-PCR, the coding sequence of RsFMOgs-oxl was successfully isolated from cDNA isolated from radish sprouts.

The sequence of RsFMOgs-oxl consists of $1353 \mathrm{bp}$, encodes 450 amino acid residues for flavincontaining monooxygenase (FMO). Similar size for FMOgs-ox proteins have been reported from other species such as Arabidopsis, human, yeast, and rice $^{4,13,35-37}$. In silico analysis of conserved sequences for FMO protein attributes such as FMO identifying motif (FxGxxxHxxxY/F), FAD- and NADPHbinding motif (GxGxxG) are evident to exists in RsFMOgs-oxl. Amino acids sequence comparison revealed that RsFMOgs-ox1 has high identity with FMO from Brassica rapa (BrFMOgs-ox1) that probably plays a role in glucosinolate biosynthesis. However, except sequence information in NCBI, there is no follow-up report for the functional study of $\mathrm{BrFMOgs-}$ oxl. Hence it is worth to notice that the RsFMOgs-oxl reported here probably also involved in glucosinolate biosynthesis. However, further work is required to confirm this feasibility.

During seedling development, RsFMOgs-oxl is highly expressed at 5 days after germination. The fact that radish seedling (sprouts) contains high glucosinolates content indicates that RsFMOgs-oxl play a potential role in the biosynthesis of these molecules. However, additional functional characterization is necessary to elucidate the mode of action of RsFMOgs-oxl in glucosinolates biosynthesis pathway. In radish, although the glucosinolates content is different among cultivars, the general pattern of glucosinolates distribution is almost similar. In the seed, the major glucosinolate is GRE, while GRH is abundant in other organs. During germination, GRE content was slowly decreased and the GRH being increased ${ }^{38}$. The conversion of GRH into GRE is mediated by FMOgs-ox enzyme. Interestingly, although the FMOgs-ox is mainly involved in GRHGRE conversion, the Arabidopsis knock out mutant did not show any significant difference for glucosinolates content in the seeds and leaves, indicating a compensation mechanism for FMOgs-ox genes member in Arabidopsis. In radish, at the moment, it is still not clear whether FMOgs-ox also exists in multi copy genes. More extensive genome wide study is required for the identification of $F M O$ genes member in radish.

Glucosinolate-derived molecules also play a role in several other biological processes such as defence against insect attack and function as disease suppression caused by fungal pathogen ${ }^{39,40}$. Experi- 
mental data from wounding treatment revealed that RsFMOgs-oxl expression is up-regulated at 1 day after wounding. This result suggests that RsFMOgs-oxI is involved in early signalling pathway for wounding stress.

Protein localization studies should provide information for the proper residence of certain protein to execute their function. Previously, $\mathrm{Li}$ et $\mathrm{al}^{13}$ reported that Arabidopsis FMOgs-ox1 is localized in the cytoplasm. Bioinformatics analysis using pSORT $^{41}$ revealed that RsFMOgs-ox 1 was predicted to be localized in cytoplasm. However, our data which is observed from stable expression in Arabidopsis revealed that RsFMOgs-ox1 is both cytosolic and nucleic protein. These data indicates that cytoplasm and nucleus are the appropriate intracellular location for RsFMOgs-ox1 to perform its function.

In summary, the result obtained from this study will be helpful for further pursuing functional studies of RsFMOgs-ox 1 and its modification. Generating transgenic lines with ectopic or knock down expression of RsFMOgs-oxl in radish and its biochemical compounds analysis, such glucosinolates content, should be very interesting challenge.

Acknowledgements: This study was supported by iPET (Korea Institute of Planning and Evaluation for Technology in Food, Agriculture, Forestry and Fisheries), Ministry of Agriculture, Food and Rural Affairs and by the GRRC Program of Gyeonggi Province (GRRC-CAU-2014-B01, Development of Baemoochae Kimchi and Postharvest Technology).

\section{REFERENCES}

1. Ciska E, Martyniak-Przybyszewska B, Kozlowska H (2000) Content of glucosinolates in Cruciferous vegetables grown at the same site for two years under different climatic conditions. J Agr Food Chem 48, 2862-7.

2. Ishida M, Kakizaki T, Ohara T, Morimitsu Y (2011) Development of a simple and rapid extraction method of glucosinolates from radish roots. Breed Sci 61, 208-11.

3. Carlson DG, Daxenbichler ME, Van Etten CH (1985) Glucosinolate in radish cultivars. J Am Soc Hort Sci 110, 634-8.

4. Hansen BG, Kliebenstein DJ, Halkier BA (2007) Identification of a flavin-monooxygenase as the $S$-oxygenating enzyme in aliphatic glucosinolate biosynthesis in Arabidopsis. Plant J 50, 902-10.

5. Razis AFA, De Nicola GR, Pagnotta E, Iori R, Ioannides C (2012) 4-Methylsulfanyl-3-butenyl isothiocyanate derived from glucoraphasatin is a potent inducer of rat hepatic phase II enzymes and a potential chemopreventive agent. Arch Toxicol 86, 183-94.
6. Barillari J, Iori R, Broccoli M, Pozzetti L, Canistro D, Sapone A, Bonamassa B, Biagi GL, Paolini M (2007) Glucoraphasatin and glucoraphenin, a redox pair of glucosinolates of Brassicaceae, differently affect metabolizing enzymes in rats. J Agr Food Chem 55, 5505-11.

7. Li J, Hansen BG, Ober JA, Kliebenstein DJ, Halkier BA (2008) Subclade of flavin-monooxygenases involved in aliphatic glucosinolate biosynthesis. Plant Physiol 148, 1721-33.

8. Schuster J, Knill T, Reichelt M, Gershenzon J, Binder S (2006) BRANCHED-CHAIN AMINOTRANSFERASE4 is part of the chain elongation pathway in the biosynthesis of methionine-derived glucosinolates in Arabidopsis. Plant Cell 18, 2664-79.

9. Textor S, de Kraker JW, Hause B, Gershenzon J, Tokuhisa JG (2007) MAM3 catalyzes the formation of all aliphatic glucosinolate chain lengths in Arabidopsis. Plant Physiol 144, 60-71.

10. Reintanz B, Lehnen M, Reichelt M, Gershenzon J, Kowalczyk M, Sandberg G, Godde M, Uhl R, Palme K (2001) bus, a bushy Arabidopsis CYP79F1 knockout mutant with abolished synthesis of short-chain aliphatic glucosinolates. Plant Cell 13, 351-67.

11. Chen S, Glawischnig E, Jørgensen K, Naur P, Jørgensen B, Olsen CE, Hansen CH, Rasmussen H, Pickett JA, Halkier BA (2003) CYP79F1 and CYP79F2 have distinct functions in the biosynthesis of aliphatic glucosinolates in Arabidopsis. Plant J 33, 923-37.

12. Naur P, Petersen BL, Mikkelsen MD, Bak S, Rasmussen H, Olsen CE, Halkier BA (2003) CYP83A1 and CYP83B1, two nonredundant cytochrome P450 enzymes metabolizing oximes in the biosynthesis of glucosinolates in Arabidopsis. Plant Physiol 133, 63-72.

13. Li J, Kristiansen KA, Hansen BG, Halkier BA (2010) Cellular and subcellular localization of flavin-monooxygenases involved in glucosinolate biosynthesis. $J$ Exp Bot 62, 1337-46.

14. Murashige T, Skoog F (1962) A revised medium for rapid growth and bio assays with tobacco tissue cultures. Physiol Plant 15, 473-97.

15. Sambrook J, Fritsch EF, Maniatis T (1989) Molecular Cloning. A Laboratory Manual, 2nd edn, Cold Spring Harbor Laboratory Press, Plainview, NY.

16. Stothard P (2000) The sequence manipulation suite: JavaScript programs for analyzing and formatting protein and DNA sequences. BioTechniques 28, 1102-4.

17. Altschul SF, Madden TL, Schäffer AA, Zhang J, Zhang Z, Miller W, Lipman DJ (1997) Gapped BLAST and PSI-BLAST: a new generation of protein database search programs. Nucleic Acids Res 25, 3389-402.

18. Johnson M, Zaretskaya I, Raytselis Y, Merezhuk Y, McGinnis S, Madden TL (2008) NCBI BLAST: a better web interface. Nucleic Acids Res 36, W5-9.

19. Sigrist CJA, Cerutti L, de Castro E, Langendijk-Genevaux PS, Bulliard V, Bairoch A, Hulo N (2010) 
PROSITE, a protein domain database for functional characterization and annotation. Nucleic Acids Res $\mathbf{3 8}$, D161-6.

20. Xu Y, Zhu X, Gong Y, Xu L, Wang Y, Liu L (2012) Evaluation of reference genes for gene expression studies in radish (Raphanus sativus L.) using quantitative real-time PCR. Biochem Biophys Res Comm 424, 398-403.

21. Livak KJ, Schmittgen TD (2001) Analysis of relative gene expression data using real-time quantitative PCR and the $2^{-\Delta \Delta C_{\mathrm{T}}}$ method. Methods 25, 402-8.

22. Cutler SR, Ehrhardt DW, Griffitts JS, Somerville CR (2000) Random GFP::cDNA fusions enable visualization of subcellular structures in cells of Arabidopsis at a high frequency. Proc Natl Acad Sci USA 97, 3718-23.

23. Clough SJ, Bent AF (1998) Floral dip: a simplified method for Agrobacterium-mediated transformation of Arabidopsis thaliana. Plant J 16, 735-43.

24. Su'udi M, Cha JY, Jung MH, Ermawati N, Han CD, Kim MG, Woo YM, Son D (2012) Potential role of the rice OsCCS52A gene in endoreduplication. Planta 235, 387-97.

25. Schmid M, Davison TS, Henz SR, Pape UJ, Demar M, Vingron M, Schölkopf B, Weigel D, Lohmann JU (2005) A gene expression map of Arabidopsis thaliana development. Nat Genet 37, 501-6.

26. Zimmermann P, Hirsch-Hoffmann M, Hennig L, Gruissem W (2004) GENEVESTIGATOR: Arabidopsis microarray database and analysis toolbox. Plant Physiol 136, 2621-32.

27. Rhee SY, Beavis W, Berardini TZ, Chen G, Dixon D, Doyle A, Garcia-Hernandez M, Huala E, Lander G, Montoya M, et al (2003) The Arabidopsis Information Resource (TAIR): a model organism database providing a centralized, curated gateway to Arabidopsis biology, research materials and community. Nucleic Acids Res 31, 224-8.

28. Ouyang S, Zhu W, Hamilton J, Lin H, Campbell M, Childs K, Thibaud-Nissen F, Malek RL, Lee Y, Zheng L, et al (2007) The TIGR Rice Genome Annotation Resource: improvements and new features. Nucleic Acids Res 35, D883-7.

29. Mueller LA, Lankhorst RK, Tanksley SD, Giovannoni JJ, White R, Vrebalov J, Fei Z, van Eck J, Buels R, Mills AA, et al (2009) A snapshot of the emerging tomato genome sequence. Plant Genome 2, 78-92.

30. Shen D, Sun H, Huang M, Zheng Y, Li X, Fei Z (2013) RadishBase: a database for genomics and genetics of radish. Plant Cell Physiol 54, e3(1-6).

31. Yeku O, Frohman M (2011) Rapid amplification of cDNA ends (RACE). Meth Mol Biol 703, 107-22.

32. Zhao SZ, Sun HZ, Gao Y, Sui N, Wang BS (2011) Growth regulator-induced betacyanin accumulation and dopa-4,5-dioxygenase (DODA) gene expression in euhalophyte Suaeda salsa calli. In Vitro Cell Dev Biol Plant 47, 391-8.

33. Xin C, Volkaert H, Chatwachirawong P, Srinives $\mathrm{P}$
(2010) Molecular cloning and expression analysis of the pathogenesis-related gene $V a P R 2$ in azuki bean (Vigna angularis). Sci Asia 36, 72-5.

34. Taheri A, Jayasankar S, Cline JA, Raizada MN, Pauls PK (2012) A WD-repeat gene from peach (Prunus persica L.) is a functional ortholog of Arabidopsis thaliana TRANSPARENT TESTA GLABRA1. In Vitro Cell Dev Biol Plant 48, 23-9.

35. Lawton MP, Cashman JR, Cresteil T, Dolphin CT, Elfarra AA, Hines RN, Hodgson E, Kimura T, Ozols J, Phillips IR, et al (1994) A nomenclature for the mammalian flavin-containing monooxygenase gene family based on amino acid sequence identities. Arch Biochem Biophys 308, 254-7.

36. Suh JK, Poulsen LL, Ziegler DM, Robertus JD (1999) Yeast flavin-containing monooxygenase generates oxidizing equivalents that control protein folding in the endoplasmic reticulum. Proc Natl Acad Sci USA 96, 2687-91.

37. Yamamoto Y, Kamiya N, Morinaka YI, Matsuoka M, Sazuka T (2007) Auxin biosynthesis by the YUCCA genes in rice. Plant Physiol 143, 1362-71.

38. O'Hare TJ, Wong LS, Force LE, Williams DJ, Gurung CB, Irving DE (2008) Glucosinolate composition and anti-cancer potential of white radish and radish sprouts. Acta Hort 765, 237-43.

39. Barth C, Jander G (2006) Arabidopsis myrosinases TGG1 and TGG2 have redundant function in glucosinolate breakdown and insect defense. Plant $J \mathbf{4 6}$, 549-62.

40. Brader G, Mikkelsen MD, Halkier BA, Palva ET (2006) Altering glucosinolate profiles modulates disease resistance in plants. Plant J 46, 758-67.

41. Horton P, Park KJ, Obayashi T, Fujita N, Harada H, Adams-Collier CJ, Nakai K (2007) WoLF PSORT: protein localization predictor. Nucleic Acids Res 35, W585-7. 